\title{
Nuut gedink oor die wese en inhoud van die dienswerk van die diaken
}

\author{
Author: \\ Gert Breed ${ }^{1}$ \\ Affiliation: \\ ${ }^{1}$ Department of Practical \\ Theology, North-West \\ University, South Africa \\ Correspondence to: \\ Gert Breed \\ Email: \\ gert.breed@nwu.ac.za \\ Postal address: \\ PO Box 1915, Noordbrug \\ 2522, South Africa \\ Dates: \\ Received: 04 Apr. 2011 \\ Accepted: 23 Mar. 2012 \\ Published: 20 July 2012 \\ How to cite this article: \\ Breed, G., 2012, 'Nuut gedink \\ oor die wese en inhoud \\ van die dienswerk van die \\ diaken', HTS Teologiese \\ Studies/Theological Studies \\ 68(1), Art. \#1059, 8 pages. \\ http://dx.doi.org/10.4102/ \\ hts.v68i1.1059
}

The essence and content of a deacon's service revisited. In many congregations, there is great uncertainty about the precise duty of the deacon within the congregation. Nowhere in the Bible is the essence and content of a deacon's service clearly spelled out. The suitability of the Scriptural passages that are often referred to to determine the essence and content of a deacon's work is widely questioned. Through the ages and in various traditions, the deacon has been entrusted with a wide variety of duties. All of the above necessitates a revisitation of the essence and content of the deacon's service. This article aims to extract the applicable aspects of the latest research on the diakon word group and apply its meaning to the work of the deacon within the overall ministry of the congregation. In order to achieve this objective, the applicable findings within research, conducted over the last 20 years, on the diakon word group is provided. Then the traditional Biblical substantiation of the essence and content of the deacon's service is critically reviewed. In conclusion, recommendations are made concerning the meaning of the latest research on the diakon word group for the deacon's service within the overall ministry of the congregation.

\section{Inleiding}

Die plek wat die diaken in die totale bediening van die gemeente moet inneem, is van vroeg af reeds betwis. Dit het saamgehang met die vraag oor die Bybelse begronding van die wese en inhoud van die diaken se dienswerk waaroor eksegete ook voortdurend verskil het. Die diakens moes weens hierdie verskille 'n ryke verskeidenheid rolle in die geskiedenis van die kerk vertolk. Hierdie artikel wil krities kyk na die tradisionele Bybelse begronding van die wese en inhoud van die diaken se werk en vanuit nuwere navorsing voorstelle oor die wese en inhoud van die diaken se dienswerk maak.

Navorsing oor die afgelope 20 jaar oor die betekenis van die diakon-woordgroep kan ingrypende betekenis vir die bediening in gemeentes hê. Daar is, sover vasgestel kon word, in Suid Afrika nog nie op wetenskaplike terrein van hierdie navorsing kennis geneem nie. Wêreldwyd is ook min geskryf oor die praktiese betekenis wat die bevindinge vir die bediening binne die gemeente en vir die dienswerk van die diaken inhou. Hierdie artikel wil sekere aspekte van die bevindinge van genoemde navorsing weergee en voorstelle oor die moontlike betekenis van hierdie navorsing vir die bediening in gemeentes, en in die besonder vir die dienswerk van die diaken, aan die hand doen. Die aanpak van die artikel ten opsigte van die navorsing oor die diakon-woordgroep is grootliks beskrywend van aard (vgl. Nel 2009:2). Eksegetiese ontleding van enkele skrifdele waarin die diakon-woordgroep voorkom en ' $n$ kritiese bespreking van resente navorsing word vir 'n opvolgartikel in die vooruitsig gestel.

In die eerste plek word toepaslike resultate van die nuutste navorsing weergegee. Daarna word krities gekyk na die vertrekpunte wat deur verskeie eksegete gebruik word vir die vasstelling van die wese en inhoud van die diaken se werk. Ten slotte word voorstelle oor die betekenis wat die nuutste navorsing oor die diakon-woordgroep vir die dienswerk van die gemeente, en in die besonder die diakens, inhou.

\section{Die betekenis van die diakon-woordgroep in die Nuwe Testament}

Die volgende bevindinge van die nuutste navorsing is ter sake vir hierdie artikel.

\section{Die diakon-woordgroep het in die Nuwe Testament nie slegs een kernbetekenis nie}

Uit resente navorsing is dit duidelik dat die betekenis van die diakon-woordgroep nie tot een kernbetekenis (soos barmhartigheidsdiens) beperk kan word nie. 
Die gesaghebbende woordeboek deur Arndt, Danker en Bauer (2000) het in hierdie nuutste uitgawe die verklaring van die betekenis van die diakon-woordgroep ingrypend verander in vergelyking met dié van vorige uitgawes. In die plek van die sterk klem op nederige liefdesdiens geniet die betekenis van 'tussenganger', 'woordvoerder' en 'verteenwoordiger' nou voorkeur:

- Diakoneo:

- tree op as 'n tussenganger of agent (Mark 10:45; Filem 13:2; 1 Kor 8:19; 2 Kor 3:3)

- die uitvoering van ' $n$ bepaalde taak waarvoor jy gestuur is (Hand 19:22)

- die uitvoering van 'n amptelike taak (1 Tim 3:10).

- Diakonia:

- dienswerk as 'n tussenganger, mediasie, 'n opdrag (2 Kor 9:12; Rom 15:31)

- 'n diens wat aan iemand bewys word (Ef 4:12; Luk 10:40)

- die amp van apostels en profete (Hand 1:17, 25; 20:24; 1 Kor 12:5)

- iets wat aan iemand gestuur word om die persoon te ondersteun (Hand 11:29)

- 'n bepaalde ondersteunende taak waarvoor iemand geroep is (Hand 6:2).

- Diakonos:

- iemand wat dien as 'n tussenganger in 'n transaksie, agent, koerier (2 Kor 6:4; 1 Tes 3:2; 2 Kor 11:23; Kol 1:7)

- iemand wat opdrag ontvang om die evangelie te verkondig (Kol 1:23; Ef 3:7)

- iemand word gestuur om 'n bepaalde taak te verrig (Rom 12:1).

Vir hierdie veranderings wat aangebring is, word telkens na die navorsing van Collins verwys. Collins (1990) maak 'n studie van die diakon-woordgroep soos dit in die Nuwe Testament en in 'n wye verskeidenheid Griekse literêre werke van die vroeg-Christelike tydperk gebruik is. Hy ondersoek elke teks waar die diakon-woorde in die Nuwe Testament voorkom. Die volgende gevolgtrekkings waartoe hy kom, is belangrik vir die onderwerp van hierdie artikel (vgl. ook Church of England 2001:33; Gooder 2006; Panikulam 1979:41; Van Klinken 1989:28-31):

- Barmhartigheidsdiens is slegs een van die betekenisvelde waarin die diakon-woordgroep voorkom en nie die kernbetekenis nie.

- Diakon-woorde het nie slegs een kernbetekenis nie; die betekenis van die woord moet telkens uit die verband waarin dit gebruik is, vasgestel word.

- Met watter betekenis die diakon-woorde ook al voorkom, dit dui op verantwoordelike dienswerk wat gedoen word in opdrag (gevolmagtig en verantwoordbaar) van iemand anders.

- In die briewe van Paulus lê die klem op die betekenis van woordvoerder (spokesperson).

- Die woorde kom ook dikwels in die Nuwe Testament voor met die betekenis van iemand wat deur 'n gemeente gestuur is om ' $n$ bepaalde taak te verrig.
- Diakonos dui op iemand wat 'n belangrike verantwoordelike taak verrig, selfs wanneer dit 'n slaaf is wat die werk doen.

- Diakonia en diakoneo dui nie primêr op dienswerk wat uit liefde vir iemand anders gedoen word nie, maar op die uitvoering van opdragte wat voortvloei uit jou gestuur wees deur God. Diens aan mense is dus primêr diens in opdrag van God.

- Die diakonos doen sy of haar werk met die persone of gemeente, wat hom of haar gestuur het en aan wie hy of sy verantwoording verskuldig is, in die agtergrond en agter hulle God as die primêre sender.

- 'n Wye verskeidenheid dienswerk word met die woordgroep beskryf.

Gooder (2006) som die belang van Collins se werk soos volg op:

In my view the most significant and persuasive outcome of Collins's interpretation is that ministry is not primarily about caring for one's neighbours but about fulfilling a task commissioned by a master (whether this be in the case of a 'normal' servant or in the case of a servant of God or of the church). This change of focus is immensely helpful as it centres the attention on the primary motivation of ministry which is the fulfilling of God's calling not just the care of one's neighbour. (p. 54)

Hentschel (2007) doen 'n onafhanklike, indringende studie van die diakon-woordgroep en toets onder meer die bevindinge van Collins deur ander manuskripte uit die Nuwe Testamentiese tyd as Collins te bestudeer en te vergelyk. Alhoewel sy in sekere opsigte van hom verskil, stem haar bevindinge met bogenoemde bevindings van Collins en Gooder ooreen.

Clarke (2000:239-250) beklemtoon dat die diakon-woordgroep in die Nuwe Testament gebruik word om die uniekheid van die leierskap in die kerk te beskryf. Dit is leierskap wat gegrond is op Christus se diakonia (Mark 10:42-45), Hy was sowel Here as dienskneg (diakonos) (vgl. Noordegraaf 1991:12,13). Sy gesag vloei voort uit sy bereidheid om te dien deur sy lewe in gehoorsaamheid aan sy Vader as losprys vir baie te gee (Santos 2003:202-208). So kon Paulus aandring op die erkenning van sy apostelskap, sy gestuur wees deur God en die gesag van sy verkondiging, maar homself ook telkens as dienskneg (diakonos) van die gemeente en die heidene voorstel. Hy sien homself nie as een wat gesag voer nie, maar as ' $n$ medewerker van ander, tog is hy seker van die gesag waarmee hy optree. In hierdie verband beskryf die woordgroep dus eerder 'n gesindheid onder alle leiers in die gemeente as 'n bepaalde inhoud soos barmhartigheidsdiens (vgl. Noordegraaf 1991:12).

Latvus (2008) toon aan dat Luther en in die besonder Calvyn se eksegese daartoe aanleiding gegee het dat die diakonia-beweging van die 19 e eeu 'projected its own life setting into the ancient texts' om daarby uit te kom dat die diakonoi wat in die Nuwe Testament genoem word, barmhartigheidswerk gedoen het. Hy toon aan dat die hele 
gemeente by barmhartigheidswerk betrokke was en dat dit nie 'n spesifieke taak van die diakonoi was nie.

Uit bogenoemde is die volgende duidelik:

- Daar kan nie sonder meer aanvaar word dat die diakonwoordgroep barmhartigheidsdiens of liefdesdiens aan jou naaste beskryf nie.

- Afvaardiging en gestuur wees, is dikwels deel van die betekenis van die diakon-woordgroep.

- Die doel van diakonia is volgens die Nuwe Testament gehoorsaamheid aan God wat die opdrag gee, en nie primêr naasteliefde nie.

- Die diakon-woordgroep word in die Nuwe Testament gebruik om die gesindheid (die gesindheid van Christus) waarmee dienswerk gedoen word, te beskryf. Hierdie gesindheid hou in dat die dienswerk in nederige diensbaarheid maar ook in die gesag van die een wat stuur, gedoen word.

\section{Die diakon-woordgroep beskryf die totale bediening van die kerk van Christus}

Resente navorsing toon dat die diakon-woordgroep nie slegs die diens van diaken beskryf nie, maar elke faset van die gemeentebediening (Noordegraaf 1991:12,13; Schwarz 1999:173; Sell 2010:60). Barnett (1995) stel dit so:

The important thing here is to see that the whole of the Church of the New Testament age was sent into the world with power and authority to serve ... all are sent for diakonia ... (p. 27)

Pitch $(2008: 43,44)$ toon aan dat Lukas in Handelinge die diakon-woorde gebruik om die totale bediening wat hy beskryf, te omsluit. Lukas gebruik hierdie woordgroep om die begin en einde (as 'n inclusio) van sy geskiedskrywing aan te dui. Aan die begin van Handelinge word die totale bediening van die apostels as diakonia aangedui (Hand $1: 16,25)$. Wanneer die diakonia van die apostels vanweë die groeiende getalle onder druk kom, word die diakonia verdeel sodat die sewe daaraan deel kry (Hand 6:1-7). Later word Paulus deur Christus tot hierdie diakonia geroep (Hand 9:15) en saam met hom baie ander (Hand 13:3; Kol 4:17). Aan die einde van Handelinge word beskryf hoe Paulus oor sy diakonia onder die heidene terugrapporteer aan die gemeente wat hom gestuur het (Hand 20:24; 21:19).

Diakonia is soos koinonia deel van die totale gemeentelewe. Koinonia en diakonia is onskeibaar deel van die lewe van die liggaam van Christus, die een skep die omgewing waarin die ander een verwesenlik kan word (Heitink 1999:278-279, 293-294). Koinonia stel die gelowige tot diakonia in staat en diakonia verdiep en verinnig die koinonia (Pao 2011:139-142 and Russel 1979:73, 53).

\section{Die diakon-woordgroep beskryf 'n verskeidenheid bedieninge in die kerk van Christus}

\section{Korintiërs 12}

In 1 Korintiërs 12 behandel Paulus die eenheid en die verskeidenheid wat daar in die liggaam van die Here bestaan. Nóg die eenheid nóg die verskeidenheid mag verwaarloos of ontken word. Hy pas die beginsel van eenheid en verskeidenheid toe op die bestaan en gebruik van die genade wat die Gees aan die gemeente skenk. In vers 4 tot 6 gee hy drie hoofpunte wat die struktuur vir die res van die hoofstuk vorm (Collins \& Harrington 1999:449; Vos 1993:260):

4 Daar is wel verskeidenheid van genadegawes (garismatoon), maar dit is dieselfde Gees; 5 en daar is verskeidenheid van bedieninge (diakonioon), en tog is dit dieselfde Here; 6 en daar is verskeidenheid van werkinge (energematoon), en tog is dit dieselfde God wat alles in almal werk.

- Vers 4 word verder in vers 7-11 uitgebou. Hier beskryf hy die genadegawes as werk van die Gees.

- Vers 5 word verder in vers 11-27 uitgebou. Hier beskryf hy verskillende bedieninge as werk van Christus die Here.

- Vers 6 word verder in vers 28-30 uitgebou. Hier beskryf hy verskeie werkinge (kragte) as werk van die Vader (Collins \& Harrington 1999:449; Vos 1993:260).

Dit gaan deurlopend om die eenheid en verskeidenheid. Ook hierdie driedeling van genadegawes, bedieninge en werkinge is een in hul oorsprong by die drie-enige God en die een kan nie sonder die ander nie, maar hulle is ook nie identies nie (Collins 1995:172; Grosheide 1957:323; Njiru 2002:105; Vos 1993:261). Thiselton (2000:930) druk die samehang van gawes, bedieninge en werkinge soos volg uit: God gee 'n verskeidenheid gawes (garismatoon) waardeur die gelowiges op verskeie wyses bekragtig word (energematoon) om ' $n$ verskeidenheid van praktiese bedieninge (diakonioon) uit te voer.

Wanneer aanvaar word dat vers 12 tot 27 die nadere beskrywing van die bedieninge (v. 5 - diakonia) is, is dit duidelik dat elke gemeentelid se bediening noodsaaklik is. Die verskillende diakonia word vergelyk met die funksie van elke ledemaat van die liggaam. Elkeen se funksie is vir die res van die liggaam nodig en elke ledemaat het al die ander se bediening nodig. Die ledemate wat die swakste lyk, is juis die nodigste en moet met die grootste eer beklee word. Die diakon-woordgroep beskryf dus 'n verskeidenheid van bedieninge binne die liggaam van Christus (Grosheide 1976:283 n. 5; Njiru 2002:104, 109).

\section{Petrus 4:10}

In 1 Petrus 4:10 word die verskeidenheid bedieninge in die gemeente duidelik uit die verhouding tussen die genadegawes wat die Gees skenk en die diakonia:

10 As goeie bedienaars van die veelvoudige genade van God moet elkeen, namate hy 'n genadegawe ontvang het, die ander dien (diakoneo) (1983 AV).

Die woord oikonomos wat hier as bedienaar vertaal is, kan ook as bestuurder vertaal word (Louw \& Nida 1988:477; Senior \& Harrington 2003:121-125; Stibbs 1978:156). Elke gelowige is 'n bestuurder wat verantwoordelikheid moet neem vir hoe hy of sy die deel van God se genade wat hy of sy ontvang het, aanwend. God se genade word sigbaar in die gelowige se lewe in onder meer die genadegawes wat hy of sy ontvang. Hierdie genadegawe moet gebruik word om ander te dien (diakoneo). Genade, genadegawe en diakonia is onlosmaaklik aan mekaar verbind (Heitink 1999:91). Die genade is veelvoudig, so ook die genadegawes en daarmee saam die diakonia (Feldmeier 2008:221; Harink 2009:4:1-7). 
Die diakon-woordgroep beskryf spontane dienswerk sowel as dienswerk waarvoor iemand geroep en gestuur is

Spontane dienswerk word as diakonia beskryf: Dit is, mense wat nie deur die gemeente of iemand anders vir 'n bepaalde taak geroep is nie, maar wat self deur God geroepe voel om te dien:

- Martha bedien (diakoneo) Jesus en die dissipels met kos (Luk 10:40).

- Vrouens dien (diakoneo) Jesus met hulle middele (Mark 15:41; Luk 8:3).

- Timoteus en Erastus het Paulus deur hulle bediening (diakonia) bygestaan (Hand 19:22).

- Stefanas en sy huisgesin het hulle tot diens (diakonia) van die heiliges gestel (1 Kor 16:15).

- Markus kon vir Paulus persoonlik tot baie diens (diakonia) wees (2 Tim 4:11).

- Mense wat ander in nood sien en hulle bystaan, doen dit aan Christus of die wat dié in nood nie bystaan nie, dien (diakoneo) Christus nie in sy nood nie (Matt 25:44).

Mense en engele wat geroep en gestuur word vir 'n besondere taak se dienswerk is diakonia:

- Die apostels se unieke roeping en taak word as diakonia beskryf (Hand 1:17 en 25).

- Paulus beskryf sy lewenstaak wat Christus hom opgedra het as diakonia (Hand 20:24; Rom 11:13; 2 Kor 4:1; 2 Kor 6:3).

- Paulus beskryf ook afsonderlike take wat aan hom opgedra is as sy diakonia (Rom 15:25; 2 Kor 9:12; Hand 12:25; 2 Kor 12:8).

- Timoteus se bediening in die gemeente is diakonia (2 Tim $4: 5)$.

- Febe is as diakonos aan die gemeente van Kengreë verbind en deur hulle na Rome gestuur om 'n bepaalde taak te vervul (Rom 16:1).

- Uit Filippense 1:1 en 1 Timoteus 3 is dit duidelik dat daar leiers in die gemeentes was wat diakonoi was.

- Archíppus het 'n besondere bediening (diakonia) ontvang wat hy noukeurig moes uitvoer (Kol 4:14).

- Die engele is dienende geeste wat uitgestuur is tot diakonia aan die mense (Heb 1:14).

Uit die voorafgaande is die volgende duidelik:

- Alle bediening in die gemeente is diakonia.

- Daar is 'n ryke verskeidenheid bedieninge (diakonia) in die gemeente.

- Ook spontane diens wat uit eie beweging vanweë 'n innerlike roeping deur God gedoen word, word as diakonia beskryf.

- Die woord diakonos word gebruik vir verskillende mense wat verskillende take verrig het.

- Genadegawes word aan gelowiges gegee om 'n verskeidenheid dienswerk (diakonia) tot opbou van die liggaam te verrig.

- Daar is mense wat deur die gemeentes geroep is om as leiers op te tree om die diakonia van die gemeente vlot te laat verloop.

\section{Kritiese beoordeling van vertrekpunte wat gebruik word om die wese en inhoud van die diakonale dienswerk te bepaal}

\section{Handelinge 6:1-7 kan nie op sigself gebruik word om die wese en inhoud van die diakonale dienswerk te bepaal nie}

Handelinge 6:1-7 is tradisioneel beskou as die locus classicus om die wese en inhoud van die diakonale dienswerk en so ook die studieveld van die diakoniek te bepaal (Campbell 2009:66; Mckee 1989:66, 67).

Die logika agter hierdie afleidings is soos volg (vgl. Earl 2002:6):

- Die weduwees se nood waaroor die Griekssprekende Jode gekla het, was 'n nood rakende versorging met materiële lewensmiddele (vgl. Collins 1990:5-45; Venter 1996b:43).

- Die sewe manne is slegs aangestel om te sorg dat die fisieke nood van hierdie vroue aandag kry.

- Omdat die sewe deur die gemeente verkies is en voor die apostels gebring en die hande opgelê is, kan afgelei word dat Handelinge 6 die instelling van ' $n$ nuwe amp beskryf.

- Daar kan aflei word dat hierdie sewe manne as diakens aangestel is omdat die diakon-woordgroep gebruik word om die plek waar die weduwees oor die hoof gesien is (daaglikse diakonia) te beskryf. Wanneer die werk tussen die apostels en die sewe verdeel word, ontvang die sewe die taak om die tafels te bedien (die diakonia van die tafels) - wat volgens hierdie benadering gelyk is aan armeversorging.

- Die diakon-woordgroep se primêre betekenis is 'tafelbediening deur 'n kelner', met ander woorde nederige liefdesdiens om in ander se behoeftes te voorsien. Die diaken se dienswerk is dus barmhartigheid (Breed, Van Rensburg \& Jordaan 2008:24).

- Daarom is die taak van die diakens vandag die insameling van die gawes en die versorging van mense in materiële nood.

- Elke diaken ontvang dieselfde taak, naamlik barmhartigheidsdiens, liefdegawes insamel tydens die erediens en hulp by die voorbereiding vir en bediening van die Nagmaal.

Ander navorsers (Breed et al. 2008:24; Coetzee 1967:48, 49; Venter 1996a:50-52) stel 'n uitbreiding van die diakens se werk voor deur Handelinge 6:4 met Handelinge 2:42 te vergelyk:

Uit Handelinge 2:42 is dit duidelik dat die gemeente daagliks volhard het in:
A - die leer van die apostels
B - en (kai) in die onderlinge gemeenskap
B - en (kai) in die breking van die brood
A - en (kai) in die gebede.

Die A-A-been word dan teruggevind in die apostels se beskrywing van hulle primêre taak volgens Handelinge 6:4: 
Maar ons sal volhard in:

A - die bediening van die Woord

A - en die gebede.

Hieruit word die volgende afleidings gemaak:

- Die apostels baken hulle werksveld in Handelinge 6:4 tot die A-A-been af.

- Die B-B-been van die ringskomposisie bly dus oor en die sewe mans wat verkies word se taak word deur die B-Bbeen van Handelinge 2:42 beskryf.

- Hierdie B-B been beskryf die onderlinge gemeenskap (koinonia).

- Die diakens se taak is dus die bevordering van die onderlinge gemeenskap. Versorging van mense in materiële nood (diakonia) is deel van hierdie bevordering van die koinonia.

- Die gemeente beoefen koinonia onder meer deur mense in nood te versorg. Hiermee word diakonia dus implisiet as 'n onderafdeling van koinonia beskou.

- Die werksveld (Woord en gebede) van die apostels is gelyk aan die werksveld van die ouderlinge wat later in gemeentes aangewys sou word (Breed et al. 2008:24).

Die praktiese gevolg van hierdie eksegese was dat die diaken se werk grootliks tot barmhartigheidsdiens beperk is. Diakonia het een deel van koinonia geword. Schutte (2003:148) skryf byvoorbeeld oor die belangrikheid daarvan dat die diakonaat ook missionêr gerig sal wees, maar hy beperk hierdie missionêre gerigtheid ook net tot barmhartigheidswerk na buite (vgl. Pao [2011] vir ' $n$ motivering van ' $n$ uitgebreide taakomskrywing vir die sewe manne in Handelinge 6).

Breed en Breed (2010:628-650) toon die volgende probleme met bogenoemde uitgangspunte aan (vgl. ook Bush 1867:59, wat reeds in 1867 inkonsekwenthede in die eksegese van hierdie gedeelte uitwys):

- Die beskrywing van probleem waaroor die weduwees gekla het, gee geen aanduiding oor die spesifieke saak waarin hulle in die daaglikse versorging oor die hoof gesien is nie.

- Die daaglikse bediening en die bediening van die tafels het waarskynlik meer as blote materiële versorging ingehou (Pao 2011:136).

- Wanneer die apostels hul eie werk tot die bediening van die Woord en gebede beperk, beteken dit nie noodwendig dat die sewe manne nie ook hierdie bediening (woord en gebede), net op 'n ander plek (by die huise) en wyse (uitleg van die apostels se getuienis), gedoen het nie (Sell 2010:61).

- Die vergelyking tussen Handelinge 2 en Handelinge 6 gaan nie op nie:

- Die volharding in die leer van die apostels ('n aksie van die gemeente; Hand 2) is nie dieselfde as die bediening van die Woord nie ('n aksie van die apostels; Hand 6) (vgl. Noordegraaf 1984:40; Phillips 2001:61; Sell 2010:61).

- Die koinonia en die breking van die brood kan nie vereng word net tot koinonia nie. Koinonia en die breking van die brood is twee nou verwante, maar tog afsonderlike sake. Die breking van die brood het waarskynlik op die viering van die Nagmaal gedui (Noordegraaf 1984:40-43; Phillips 2001:61).

- Die bediening van die Woord deur die apostels was oog- en oorgetuienis en kan nie gelyk gestel word aan die werk van die latere ouderlinge nie.

- Nederige liefdesdiens is nie die primêre betekenis van die diakon-woordgroep nie.

- Dat die sewe manne verkies, voor die apostels gestel en die hande opgelê is, dui nie noodwendig op die instelling van 'n nuwe besondere diens (amp) nie (Sell 2010:62).

Sell (2010:59) asook Van Klinken (1989:56) kom tot die gevolgtrekking dat die besondere diens van diaken nie op Handelinge 6 begrond kan word nie, maar dat daar wel riglyne vir die diakonia van die gemeente uit hierdie gedeelte verkry kan word (vgl. ook Bruce 1977:130, 131; Chance 2007:105).

\section{Daar kan wel riglyne vir die diakonia van die gemeente vanuit Handelinge 6 verkry word}

Die volgende afleidings kan wel uit Handelinge 6:1-7 gemaak word (Breed \& Breed 2010; Sell 2010:63-65):

- Die bediening van lidmate (diakonia) is 'n baie hoë prioriteit binne die gemeente. Wanneer lidmate se probleme doeltreffend aandag kry (versorging na binne), skep dit die omgewing waarbinne die Woord na buite uitgedra kan word (uitreik).

- Die dienswerk (diakonia) van leiers in die gemeente kan verdeel word wanneer dit te veel raak.

- Spesialisasie in die dienswerk (diakonia) is nodig by die verdeling daarvan.

- Leiers behoort 'n fokusgebied in hulle bediening (diakonia) te hê en mag nie toelaat dat hulle primêre roeping agterweë bly omdat hulle aan te veel dinge probeer aandag gee nie.

- Die gemeente kan by die verkiesing van leiers vir 'n besondere taak betrokke wees.

- 'n Konkrete noodsituasie kan daartoe aanleiding gee dat leiers gekies moet word om daardie besondere probleem te takel. Die roeping en verkiesing van leiers is deel van 'n aktuele en dinamiese groeiproses binne die gemeente.

Wanneer ander Skrifgedeeltes hiermee vergelyk word, word dit duidelik dat hierdie beginsels ook verder in die Nuwe Testamentiese kerk toegepas is.

\section{Die diens van die diaken kan nie sonder meer in alle Skrifdele wat nederige liefdesdiens beskryf, begrond word nie}

Sommige navorsers gaan uit van die standpunt dat al Jesus se woorde en dade bestudeer kan word om die wese en inhoud van die diaken se dienswerk te bepaal (Combrink 1968:37, 165; Pascal 1992:747; Van Wyk 2009:21). Die diakonale dienswerk en die diakoniek as studieveld word vanuit hierdie vertrekpunt aan die hand van verskeie tekste wat oor 
diensbaarheid handel, bepaal (Venter 1996a). Hierdie tekste word bestudeer met die voorveronderstelling dat diakonia (en daarmee die diaken se dienswerk) barmhartigheidsdiens as deel van koinonia beskryf (Gooder 2006:34). Skrifgedeeltes soos Romeine 12:8-21 word beskou as 'n beskrywing van die werk waarvoor die diakens die gemeente moet toerus (Breed et al. 2008:24; Venter 1996a:53). Alhoewel Romeine 12:8-21 opdragte oor onderlinge liefde en liefde na buite bevat, sê Paulus nêrens in hierdie gedeelte dat hy die diakonale funksie van die gemeente hiermee beskryf nie.

Collins (1990) bepaal hom in sy navorsing oor die diakonale dienswerk net by Skrifgedeeltes waarin die diakonwoordgroep voorkom en betwis die geldigheid daarvan om byvoorbeeld Johannes 13 as beskrywing van Jesus se diakonia te bestudeer omdat Johannes hierdie optrede van Jesus nie as diakonia beskryf nie (vgl. ook Gooder 2006:50). Hentschel (2007:1) sluit hierby aan deur te sê dat die Duitse Protestantse kerke se begrip oor diakonia verkeerdelik eerder op 'texten zum Thema Nächstenliebe' as op die bestudering van die Griekse woord diakonia gebou is. Nog 'n groep navorsers beklemtoon dat ' $n$ woordstudie van die diakon-woordgroep wel belangrik is, maar dat die betekenisvelde van hierdie woordgroep in die lig van die wyer Skrifverband bepaal moet word. Die betekenisveld waarin die diakon-woordgroep gebruik word, moet telkens bepaal word deur deeglike eksegese van die Skrifdeel waarin dit voorkom (Barnett 1995:21-24; Clarke 2000:240; Craighill 2006:3; Gooder 2006:50, 51).

In hierdie artikel word by laasgenoemde standpunt aangesluit.

\section{'n Begronding van die diaken se dienswerk in bedieningspatrone wat in die Nuwe Testament beskryf word, moet op deeglike eksegese rus}

Die praktyk van die dienswerk van die diaken word dikwels begrond op enkele tekste wat met mekaar in verband gebring word en waaruit 'n bedieningspatroon afgelei word:

Uit Filippense 1 en 1 Timoteus 3 is dit duidelik dat daar leiers in die gemeente was wat met die woord diakonos benoem is (Fowl 2005:20; Van Klinken 1989:57). Op albei plekke word hulle saam met die ouderlinge genoem. Hulle werk word dus aan die een kant nou met dié van die ouderlinge verbind, maar tog ook van die van die ouderlinge onderskei. Die aanname wat egter gemaak word dat hierdie diakonoi in dieselfde besondere diens (amp) as die sewe manne (Hand 6) gestaan het (Mckee 1989:69; Sell 2010:62, 63), word bloot begrond op die feit dat die diakon- woordgroep in albei gevalle gebruik word (Breed et al. 2008:24). Collins (2002:88) waarsku daarteen om diakonoi in hierdie twee tekste met die woord 'diakens' te vertaal omdat dit daartoe aanleiding kan gee dat die huidige siening van die diaken-amp in die teks ingelees word.

Die diakon-woordgroep word in die Nuwe Testament gebruik om ' $n$ wye verskeidenheid dienswerk te beskryf. Die sewe manne (Hand 6) word nêrens diakonoi genoem nie en die inhoud van die dienswerk van die diakonoi van Filippense 1 en 1 Timoteus 3 word ook nêrens beskryf nie. Hierdie verklarings sit dikwels met 'n probleem ten opsigte van die vroue wat in 1 Timoteus 3 genoem word asook met Febe wat 'n diakonos genoem word. Dit lei daartoe dat dieselfde woord uit die diakon-groep, sonder gronde, op verskillende plekke verskillend vertaal en verklaar word. Een Skrifdeel word dan gebruik om die dienswerk van die diaken te bepaal en die ander word, ongemotiveerd, nie daarvoor gebruik nie. 'n Voorbeeld hiervan is dat daar dikwels sonder meer aanvaar word dat daar in Filippense 1:1 van diakens sprake is, maar dan word diakonon in Romeine 16:1 met dienares vertaal en Febe word nie as 'n diaken beskou nie (vgl. 1933AV).

De Klerk en Dreyer (2007:213) stel dat die wesenseienskappe van die gemeentes volgens die Nuwe Testament in vier bedieninge beskryf word, naamlik kerugma, leiturgia, koinonia en diakonia. Hulle verwys na Handelinge 2:42-47 om hierdie stelling te staaf. Nie een van die bedieninge word egter in Handelinge 2:42-47 afsonderlik as diakonia aangedui nie. Dit is duidelik dat hulle die breking van die brood ongemotiveerd aan diakonia gelyk stel en diakonia tot barmhartigheidsdiens beperk. Struwig (2004:3) dui aan dat koinonia ook armeversorging ingesluit het; hy beskou diakonia as die versorging van lidmate aan mekaar. Diakonia is dan die 'praktiese voortvloeisel' van koinonia (Struwig 2004:25). Hiermee vloei diakonia en koinonia ineen.

Daar moet versigtig omgegaan word met Skrifdele wat dikwels as klinkklare gronde gebruik word om die wese en inhoud van diakonale dienswerk te bepaal. Root (1985:157) vra of bedieningspatrone wat in die Nuwe Testament beskryf word vandag enigsins as normatief vir die bediening aanvaar kan word. Hy sê dat daar baie duidelik aangetoon moet word dat ' $n$ bepaalde bedieningspatroon nie net beskryf word nie, maar ook voorgeskryf word voordat dit as normatief vir die bediening vandag beskou kan word (vgl. ook Mckee 1989:71; Sell 2010).

Uit die voorafgaande is die volgende duidelik:

- 'n Mens kan nie noodwendig enige Skrifdeel wat liefdesdiens beskryf, gebruik om die wese en inhoud van die dienswerk van die diaken te bepaal nie.

- Daar moet met omsigtigheid te werk gegaan word wanneer Skrifdele met mekaar in verband gebring word om die wese en inhoud van die diaken se dienswerk te bepaal.

- Daar word nie in die Nuwe Testament 'n duidelike taakomskrywing vir die diakens gegee nie.

- Dit is wel duidelik dat daar in die vroeë kerke mense as leiers na vore getree het wat leiding geneem het ten opsigte van die fasette van die diakonia wat nie deur die apostels of die ouderlinge hanteer kon word nie. Hulle is met die woord diakonos benoem of hulle werk is as diakonia aangedui. 


\section{Voorstelle oor die implikasies van die nuutste navorsing oor die diakon-woordgroep vir die dienswerk van die gemeente en in die besonder die diakens}

Die bevindinge waartoe in hierdie artikel gekom is, sal nou op die praktyk van die bediening toegepas word. Die bevindinge uit die navorsing word telkens as opskrif gegee en daarna volg die praktiese toepassing.

\section{Diakonia beskryf ' $\mathrm{n}$ ryke verskeidenheid bedieninge van die gemeente}

Die hele gemeente moet begelei en toegerus word om hulle gawes te gebruik om die diakonia van Christus binne en buite die gemeente te verrig. Die Gees deel die gawes uit soos Hy wil en daarom moet die omgewing geskep word waarbinne elke lidmaat haar of sy besondere dienswerk kan verrig. Lidmate behoort onderrig te word in die volle betekenis van die diakonia van Christus, naamlik dat dit nederige dienswerk is in gehoorsaamheid aan God wat die opdrag gee en daarom ook op sy gesag geskied. Lidmate behoort geroep en gestuur of afgesonder te word vir bepaalde take waaroor hulle aan die gemeente moet terugrapporteer. Lidmate behoort die geleentheid gegee te word om spontaan in ' $n$ bepaalde faset van diakonia in die gemeente leiding te neem, onder toesig van die ouderlinge. Die gemeente moet hierdie mense, wat waarlik diakonoi is, erken as diensknegte van God (1 Kor $16: 15,16)$

\section{Die diakon-woordgroep kan dui op iemand wat vir' $n$ bepaalde taak geroep en gestuur of afgesonder word}

Leiers kan, volgens die behoefte in die gemeente, afgesonder word om op spesifieke terreine van die diakonia leiding te neem.

Leiers moet die lidmate in staat stel om hul gawes te gebruik. Wanneer die diakonia in die gemeente plaasvind soos God dit wil, sal daar waarskynlik groei wees en kan die werk vir leiers te veel raak. Dan moet daar nog leiers geroep en gestuur (afgesonder) word om 'n besondere taak te verrig of om op die lang termyn as leier in 'n bepaalde diakonia op te tree.

\section{Die woord diakonos word in die Nuwe Testament soms as 'n tegniese term gebruik om bepaalde leiers in die kerk aan te dui}

Gelowiges wat in die organisering van en toerusting vir ' $n$ bepaalde faset van die diakonia leiding neem, kan as diakens vir daardie taak bevestig word.

\section{Die apostels en ouderlinge se diakonia word duidelik van ander fasette van die gemeente se diakonia onderskei}

Diakens neem leiding in die take wat nie uitsluitlik ouderlinge se taak is nie. Die ouderling se taak word deeglik in die
Nuwe Testament beskryf. Sommige eksegete interpreteer Skrifgedeeltes soos 1 Korintiërs 11 so dat sekere fasette van die diakonia van die gemeente uitsluitlik die taak van die ouderling is en dat vroue byvoorbeeld hiervan uitgesluit is. Volgens die werkverdelingsbeginsel van Handelinge 6 kan die diaken leiding neem in alle aspekte wat nie beskou word as beperk tot die ouderlinge se werksveld nie.

\section{In die Nuwe Testament word verskeie leiers genoem wat in ' $n$ bepaalde faset van die diakonia leiding geneem het}

Dit is nie duidelik of elkeen van die mense wat in die Nuwe Testament diakonos genoem word wel in ' $n$ besondere diens (amp) gestaan het nie. Die klem was op die diakonia wat verrig is en nie op 'n formele struktuur of benaming van 'n posisie nie. Wat duidelik is, is dat hulle erkende leiers was aan wie se leiding die gemeente hulle onderwerp het en dat hulle in die diakonia leiding geneem het. Dit is moontlik dat die diakonoi van Filippense 1:1 en 1 Timoteus 3 hierdie leiers in verskillende fasette van die diakonia was. Indien aanvaar word dat diakonoi wat in die diakonia leiding geneem het uiteindelik formeel as leiers (diakens) beskou is, kan die volgende daaruit afgelei word.

Alle diakens neem nie op alle terreine van die diakonia leiding nie. Diakens word vir 'n besondere deel van die diakonia ${ }^{1}$ geroep. Daar kan dus diakens wees wat in byvoorbeeld die opneem van die liefdegawes tydens die erediens of die armversorging of die wyksbediening of die hospitaalbesoek of kinderbediening of die jeugbediening of die bejaardesorg of pastorale berading leiers is. So kan daar in elkeen van die fasette van die diakonia, soos die behoefte ook al ontstaan, 'n diaken wees wat leiding neem. Daar is dus nie 'n vaste pakket take waarby elke diaken betrokke is nie; elkeen word vir ' $n$ besondere taak geroep en hy of sy spesialiseer in daardie deel van die diakonia.

\section{Slot}

Die plek van die diaken in die leierstruktuur van 'n gemeente kan uit die resultate van hierdie navorsing soos volg geformuleer word:

- Die ouderlinge en die predikant se spesialiteitsterrein van die diakonia word afgebaken.

- Die res van die diakonia van die gemeente staan onder leiding van diakens.

- Elke diaken word volgens sy of haar gawes vir 'n besondere taak of take geroep en bevestig.

- Die diakens het ' $n$ leidinggewende en toerustende rol om die gemeente in die uitvoering van hulle diakonia by te staan.

- Wanneer daar in die gemeente 'n besondere behoefte, roeping of probleem ontstaan, kan die gemeente lidmate, wat geskik is vir die taak, roep en afsonder om daardie besondere diakonia te verrig of leiding daarin te neem. Die persoon dien dan as diaken totdat die taak afgehandel is.

1.Vergelyk Calvyn se standpunt dat daar twee tipes diakens kan wees. Die een groep wat die administrasie van die barmhartigheidsdiens behartig en die ander groep (uitsluitlik vroue) wat spesialiseer in die daadwerklike versorging van armes en siekes (Mckee 1989:64-72). 


\section{Erkenning Mededingende belange}

Die outeur verklaar dat hy geen finansiële of persoonlike verbintenis het met enige party wat hom nadelig kon beïnvloed in die skryf van hierdie artikel.

\section{Literatuurverwysings}

Arndt, W., Danker, F.W. \& Bauer, W., 2000, A Greek-English lexicon of the New Testament and other early Christian literature: Based on Walter Baur's GriechischesDeutsches Wörterbuch zu den Schriften des Neuen Testaments und der übrigen urchristlichen Literatur, 3rd rev. edn., University of Chicago Press, Chicago.

Barnett, J.M., 1995, The Diaconate: A Full and Equal Order, rev. edn., Trinity Press International, Valley Forge.

Breed, D.G., Van Rensburg, F.J. \& Jordaan, J.C., 2008, Manlik en vroulik in die kerk Geslagtelikheid en die besondere dienste, Potchefstroomse Teologiese Publikasies, Potchefstroom.

Breed, G. \& Breed, D.G., 2010, 'Besinning oor die diakonale dienswerk na aanleiding van Handelinge 6:1-7', In Die Skriflig 44(3/4), 627-653.

Bruce, F.F., 1977, The book of Acts: New London Commentaries, Marshall, Morgan \& Scott, London.

Bush, G., 1867, The Christian ministry considered in relation to the priesthood of believers and the free exercise of spiritual gifts, Longmans, London.

Campbell, J.C., 2009, Phoebe: Patron and Emissary, Liturgical Press, Collegeville.

Chance, J.B., 2007, Acts, Smyth and Helways Bible Commentary, Smyth and Helwys Publishing, Macon.

Church of England, House of bishops, Working party, 2001, 'For such a time as this: A renewed diaconate in the Church of England: A report to the General Synod of the Church of England of a working party of the House of Bishops', Church House Publishing, London.

Clarke, A.D., 2000, Serve the Community of the Church: Christians as Leaders and Ministers: First-Century Christians in the Graeco-Roman World, Eerdmans, Grand Rapids.

Coetzee, J.C., 1967, 'Enkele Skrifgegewens oor die diakenamp: Handelinge 6 en die diakenamp', In die Skriflig 1(4), 44-49.

Collins, J.N., 1990, Diakonia: Re-interpreting the Ancient Sources, Oxford University Press, Oxford.

Collins, J.N., 1995, 'A Ministry for tomorrow's church', Journal of Ecumenical Studies $32(2), 159-178$.

Collins, J.N., 2002, Deacons and the church: Making connections between old and new, Gracewing Publishing, Herefordshire.

Collins, R.F. \& Harrington, D.J., 1999, First Corinthians, Liturgical Press, Collegeville.

Combrink, H.J.B., 1968, 'Die diens van Jesus: 'n Eksegetiese beskouing oor Markus 10:45', Academisch Proefschrift, V.R.B.- Offsetdrukkerij, Groningen.

Craighill, P.G., 2006, 'John N. Collins, Diakonia: Re-interpreting the Ancient Sources', in Bryn Mawr Classical Review, viewed n.d., from http://bmcr.brynmawr. edu/1991/02.05.06.html

De Klerk, B.J. \& Dreyer, T.F., 2007, 'Die rol van die gemeente as geloofsgemeenskap in die begeleiding tot belydenisaflegging', In die Skriflig 41(2), 209-231.

Earl, S.J., 2002, The Presbyterian Deacon: An Essential Guide, Geneva Press, Louisville.

Feldmeier, R., 2008, The first letter of Peter: A commentary on the Greek text, Baylor Univarsity Press, Waco.

Fowl, S.E., 2005, Philippians: The two horizons commentary, Wm. B. Eerdmans Publishing, Cambridge, viewed 02 October 2010, from http://books.google.co.za

Gooder, P., 2006, 'Diakonia in the New Testament: A Dialogue with John N. Collins', Ecclesiology 3(1), 33-56, viewed 10 February 2008, from http://dx.doi. org/10.1177/1744136606067678

Grosheide, F.W., 1957, De eerste brief aan de kerk te Korinte, Kok, Kampen.

Grosheide, F.W., 1976, The first epistle to the Corinthians. The New International commentary on the New Testament, Michigan, Eerdmans.

Harink, D., 2009, 1\&2 Peter, Brazos Print, Grand Rapids.
Heitink, G., 1999, Practical theology: History, theory, action domains: Manual for practical theology, Eerdmans, Grand Rapids.

Hentschel, A., 2007, Diakonia im Neuen Testament: Studien zur Semantik unter besonderer Berücksichtigung der Rolle von Frauen, Mohr Siebeck, Tübingen.

Latvus, K., 2008, 'The Paradigm Challenged A New Analysis of the Origin of Diakonia', Studia Theologica 62, 142-157, viewed 19 November 2011, from http://dx.doi. org/10.1080/00393380802559816

Louw, J.P. \& Nida, E.A., 1988, Greek-English Lexicon of the New Testament: Based on Semantic Domains, 2nd edn., United Bible Societies, New York.

Mckee, E.A., 1989, Diakonia in the classical reformed tradition and today, Eerdmans, Grand Rapids.

Nel, M., 2009, 'Congregational analysis revisited: Empirical approaches', HTS Teologiese/Theological Studies 65(1), Art. \#187, 13 pages, viewed 18 September 2011, from http://dx.doi.org/10.4102/hts.v65i1.187

Njiru, P.K., 2002, Charisms and the Holy Spirit's activity in the body of Christ: An exegetical-theological study of 1 Corinthians 12, 4-11 and Romans 12, 6-8, Gregorian Univarsity Press, Rome.

Noordegraaf, A., 1984, Creatura Verbi: De groei van de gemeente volgens de Handelinge der Apostelen, Boekencentrum B.V., 'S-Gravenhage.

Noordegraaf, A., 1991, Theologie in reformatorish perspectief: Oriëntatie in het diakonaat, Boekenzentrum B.V., Zoetemeer.

Panikulam, G., 1979, Koinōnia in the New Testament: A dynamic expression of Christian life, Pontificio Istituto Biblico, Rome.

Pao, D.W., 2011, 'Waiters or Preachers: Acts 6:1-7 and the Lukan Table Fellowship Motif', Journal Of Biblical Literature 130(1), 127-144.

Pascal, R.W., 1992, 'Service', in J.B. Green, S. Mcknight \& I.H. Marshall (eds.), The Dictionary of Jesus and the Gospels, pp. 747-751, Intervarsity Press, Downers Grove/Leicester, England.

Phillips, J., 2001, Exploring Acts: An expository commentary, Kregel publications, Grand Rapids.

Pitch, J.J., 2008, Paul's social network: Brothers and sisters in faith. Stephen: Paul and the Hellenist Israelites, Liturgical Press, Collegeville.

Root, M., 1985, 'Called to the Office of Ministry: The New Testament and Today', Theology and Mission 12(3), 157-166.

Russel, L.M., 1979, The future of partnership, Westminister Press, Philadelphia.

Santos, N.F., 2003, Slave of all: The paradox of authority and servanthood in the Gospel of Mark, Sheffield Academic Press, London.

Schwarz, C.A., 1999, Paradigm shift in the church: How natural church development can transform theological thinking, C\&P Verlag, Emmelsbüll.

Schutte, P.J.W., 2003, 'Missionêre diakonaat: 'n Uitdaging vir die kerk', HTS 59(1), 247-264.

Sell, P.W., 2010, 'The seven in Acts 6 as a ministry team', Bibliotheca Sacra 167(1), 58-67.

Senior, D. \& Harrington, D.J., 2003, 1 Peter, Jude and 2 Peter, Liturgical Press, Collegeville.

Stibbs, A.M., 1978, The first epistle general of Peter: Tyndale New Testament Commentaries, Tyndale Press, Grand Rapids.

Struwig, O.J., 2004, 'Die verhouding gemeenskap van die gelowiges en die dienswerk van die diakens: 'n Prakties-teologiese studie. Met spesifieke verwysing na die "sewe" (Handelinge 6)', MTh. Skripsie, Theology Department, Noordwes Universiteit.

Thiselton, A.C., 2000, The First Epistle to the Corinthians: A commentary on the Greek text, Wm. B. Eerdmans Publishing, Grand Rapids.

Van Klinken, J., 1989, Diakonia: Mutual helping with justice and compassion, Kampen, Kok.

Van Wyk, G.J., 2009, 'Die implikasie van die diakonia van Jesus in woord- en daadverkondiging in die Markus-evangelie: 'n Eksegetiese studie', ThD proefskrif, Theology Department, Noordwes Universiteit.

Venter, C.J.H., 1996a, "n Teorie vir diakoniek: 'n Poging tot nuwe denke met besondere verwysing na die diakonaat en geregtigheid', Praktiese Teologie in Suid Afrika 11(1), 48-57.

Venter, C.J.H., 1996b, Uitkringende Liefdesbetoon. Kommunikatiewe handelinge in diens van die onderlinge liefdesgemeenskap in die kerk, Raad vir Geesteswetenskaplike Navorsing, Pretoria.

Vos, J.S., 1993, 'Das Rätsel von i Kor 12:1-3', Novum Testamentum 35(3), 251-269, viewed 06 January 2011, from http://www.jstor.org/stable/1561542 